\title{
Ras-Related Protein Rab-23
}

National Cancer Institute

\section{Source}

National Cancer Institute. Ras-Related Protein Rab-23. NCI Thesaurus. Code C106459.

Ras-related protein Rab-23 (237 aa, $27 \mathrm{kDa}$ ) is encoded by the human RAB23 gene.

This protein is involved in both intracellular signaling and intracellular membrane trafficking. 